\title{
Sujeitos Históricos: seus Lugares na Escola e na Formação de Professores*
}

\section{Célia Frazão Linhares}

Universidade Federal Fluminense (UFF)

Não lc percas tão miseravelmente $\mathrm{cm}$ teus pensamentos.

SHAKESPEARE

...o pobre é a garantia de uma visão de futuro.

MILTON ALMEIDA DOS SANTOS

A tragédia social e educacional brasileira perdura e se aprofunda pela ausência, na sociedade brasileira, de uma conjugação de forças que represente uma paixão para revertê-la. Uma paixão política que se entrelace com a busca de saberes e conhecimentos, que se alimente de uma curiosidade por compreender os mecanismos de opressão, representando uma forma de afirmação da vida, em que o sabor esteja implicado na ampliação e apropriação do saber pela ação dos sujeitos históricos nele envolvidos. Uma das vias para reinventarmos a Educação de Professores é empreendermos uma "arqueologia da escola " em busca de sonhos e conflitos nela já vividos para ressignificá-los em projetos de uma nova instiuição escolar.

\section{A maior tragédia da escola pública brasileira é que ela convive com o conformismo da sociedade}

Em meio a tantas informações e teorias que se autodefinem como verdadeiras e científicas, que não param de se amontoar, trazendo a impressão

-Uma versão do presente artigo foi publicada em SILVA JUNIOR, Celestino, RANGEL, Mary (Orgs.). Nove olhares sobre a supervisão. Campinas: Papirus, 1997. 
de que algo de importante e decisivo está para ser descoberto, inventado, anunciado, a crise da escola pública - que reflete e aprofunda a perda do exercício ético entre nós - continua a desafiar nossa capacidade de formulação e, por conseguinte, de intervenção.

O desastre educacional produzido dentro da escola, que todos sabemos estar interligado aos processos crescentes de exclusão social, vem sendo pouco referido à sua dimensão simbólica, à construção histórica de valores e significados comuns, sem os quais não é possível elaborar um projeto pedagógico. Para construir o sentido de uma sociedade, não se pode manter barreiras entre sua produção material e sua produção simbólica. Uma e outra se condensam na definição do que somos e do que queremos ser, que funda e sustenta nossa própria ação política.

A problemática educacional tem sido tratada como uma subsidiária das questões econômicas e financeiras, tanto na perspectiva conservadora e liberal - com que se alinha a nova direita - quanto no tratamento elaborado pelas versões vulgares do socialismo e do materialismo histórico-dialético, que se articulam no campo progressista.

Em outras palavras, se dependemos quase exclusivamente das análises econômicas para nossos estudos e explicações do processo social e educativo, é importante sublinhar que a esfera da produção não saiu ex nihilo, mas vem sendo partejada por embates tramados historicamente, quer dizer, fermentados, na cultura, marcados pelo acervo da memória social, saturados de imagens que, por serem pouco discutidas, funcionam como um a priori, legitimando alguns exercícios do poder, em detrimento de outros.

Agora, por exemplo, a classe dirigente insiste em apresentar promessas de solução para as graves questões nacionais, mediante as privatizações (como expressão de políticas neoliberais) e a repressão policialesca (como uma das faces do neoconservadorismo), enquanto nega à sociedade brasileira sua participação na construção de um processo civilizatório. Na atual refundação capitalista não há lugar para escolhas de sujeitos históricos: a opção colocada está presa à lógica da competição sem trégua, em que, por um lado, impõe-se a vitória dos mais fortes, num verdadeiro darwinismo social, para ser consolidada 
com a legitimação, ainda que dada de forma passiva pelos derrotados, e, por outro, profetiza-se a aproximação do caos, da barbárie. O dilema estabelecerse-ia com a seguinte "escolha": engole-se a tirania, o que corresponderia a se resignar com ela, ou sua exacerbação vai acabando por aniquilar o que ela própria proclama defender: as possibilidades de vida social.

Ao minimizarmos o esforço humano e social para submeter a ordem cotidiana a um exercício de reinvenção - em que a memória seria restaurada como um baú de sonhos não realizados, de conflitos ainda não extintos e, portanto, de fonte de criação que tensiona o instituído no sentido de sua superação em busca de maior solidariedade ${ }^{1}$, perdemos um solo ético de fundamental importância para a educação.

Como podemos olhar, descrever, estudar a questão da escola pública, sem estremecermos diante dela?

Como podemos nos perder tão miseravelmente num jogo de pensamentos que se dissolvem em aplausos ou em efeitos de eco, sem que as elaborações sejam seriamente assumidas como instrumentos de intervenção da realidade? Afinal, no estado em que a escola pública se encontra já representa um intenso argumento inviabilizando as esperanças de diálogo, de interlocução, sem as quais a escola não encontra sustentação possível.

Só mesmo uma forte naturalização das desigualdades - que nos esconde seu profundo enraizamento histórico, com que vai se alimentando a razão cínica ${ }^{2}$ que nivela todos os atos a uma avaliação utilitária e particularista - é que torna possível que não nos assustemos com a desintegração da escola pública. Sem escola pública que possibilite uma aprendizagem do conhecimento como uma tensão emancipatória, como realizar o fundamental exercício de escolhas em que cada nação define concretamente sua presença nessa rede de interdependências que vai se tornando cada vez mais intensa.

'Não podemos esquecer que o mito grego concebe as musas, de quem a poesia receberia um lampejo inspirador, como fillhas de Zeus e de Mnemósina, a deusa da memória, que representaria uma guardiã contra o esquecimento.

${ }^{2} S A ́$ em 1988, Costa (1994, p.40) usara essa expressão para analisar "o descrédito das leis e o ataque ideológico à idéia do sujeito moral ideal", referenciando-se em estudos de Sloterdijk. 
Não podemos minimizar a importância que a escola e a cultura letrada exercem no sentido de frear os imediatismos das reações e de ampliar os instrumentos não só para a sobrevivência humana mas, sobretudo, para a compreensão da trama histórica e das escolhas alternativas de respostas que cada sociedade pode ter e que podem constituir-se como projetos.

Mas bem sabemos, que não é qualquer escola que irá nos ajudar a responder às graves questões intensificadas nesse período de crise. Sem uma escola pública que nos permita aceder à palavra, desnaturalizar as iniquidades com que fizemos nossa história, elaborar projetos coletivos e individuais, ou seja, sonhar com outros mundos, será bem mais difícil sair deste abismo onde a miopia, própria da luta pela sobrevivência, nos mantém.

A rigor, sob intensas ameaças de excludência física e moral, a ânsia de sobreviver que marca este final de século aproxima-se da selvageria com que o capitalismo se estruturou, no século XVII, o que fez Hobbes concluir que "o homem é o lobo do homem".

Em países do capitalismo periférico, como o nosso, em que os direitos civis, sociais e humanos sempre primaram por sua função de adereço, pendentes de uma retórica que primou pela convivência com a iniqüidade, com a injustiça, legitimados pelos usos e costumes, a organização da sociedade e a noção da própria humanidade foram se impregnando de hierarquias e conflitos. Uns seriam mais humanos que outros.

Roberto da Matta explorou a expressão "sabe com quem está falando?", para nos mostrar os limites das discussões em face de um escalonamento de privilégios muito assentado na nossa estrutura social.

Darcy Ribeiro ( 1995), remexendo nossa herança coletiva, registrou que "levamos sempre conosco a cicatriz de torturador impressa na alma e pronta a explodir na brutalidade racista e classista."

Em conseqüência de tudo isso, a indignação parece cabível quando privilégios já naturalizados são feridos ou ameaçados. Só alguns poucos têm espaço para a indignação, ${ }^{3}$ com seus mecanismos de terror; para os demais

Balançamos em movimentos pendulares entre duas esferas de valor: "uma indignada e furiosa, outra generosa e condescendente, c acreditamos com isso salvar a própria pele."(Castello, 1994, p.16) 
caberia esperar pelas concessões e favores. Oscila-se assim entre a violência ativa - ora dirigida aos destituídos de poder, ora por eles acionada, e a violência passiva - autodirigida pelas próprias vítimas, e que redundam em um conformismo que cresce com o crescimento das excludências e suas ameaças. Uma e outra exprimindo a banalização da vida. Isto equivale à alternância das duas faces de uma mesma moeda: a moral da sobrevivência e o jogo de luz do espetáculo narcísico. Afinal, não podemos esquecer que, entre nós, o limite que separa o herói do vilão é sempre poroso, precário.

Somente a pulverização dos significados sociais pode nos atirar nesse vale-tudo e, portanto, nesse nada-vale, nos fazendo espectadores de um processo como o que vem vivendo a escola pública brasileira, quando se lhes arranca uma identidade social, denegando aos alunos e professores o acesso a saberes e conhecimentos, a uma elaboração de um autoconhecimento pela partilha das experiências coletivas, como matrizes de projetos, expectativas e esperanças, com que viabilizaríamos nosso presente, que sempre se faz como uma travessia para o futuro.

No nosso caso, para qual futuro?

Numa época em que o próprio exercício ético exige um nível complexo de organização de conhecimento, quando a identidade nacional supõe a elaboração coletiva de símbolos e significados sociais (Castells, 1990), é preciso encarar que um tipo de educação escolar, que não atinge os sujeitos históricos, obstrui nossa participação nacional nesse processo de interdependência da cultura e da economia, que nos vem sendo imposto num circuito homogeneizador e opressivo.

Isto nos lança um desafio em dose dupla: ampliar a escola, ampliando internamente seus espaços de atuação de sujeitos.

Sabemos que o sujeito é sempre conquista contra o assujeitamento: assujeitamento material, mas também assujeitamento moral, que são operados simultânea e interligadamente. A servidão se faz norma quando os "educados" comandam o espetáculo social, exibindo instrumentos de cálculos e planos, justificados em sua dureza pela suposta função de impedir o caos, a exclusão, a guerra que não param de promover. Guerras que mais que os bens materiais 
destroem hoje sociedades, classes e grupos sociais e pessoas em verdadeiros "assassinatos culturais", para usar uma expressão de Glauber Rocha.

Não podemos esquecer que são os que dispõem de um alto nível de escolaridade e que pertencem às classes dirigentes que comandam os grandes crimes contra a humanidade, embora a imagem do ladrão e do delinqüente seja atribuída, com freqüência aos pobres, aos negros e mestiços, aos gays. Contra eles é imputada a responsabilidade sobre os problemas nacionais: são eles apontados como a causa da violência urbana, do desemprego, do atraso nacional, das endemias e epidemias, da falta de aprendizagem escolar e por aí vai...

São, ainda, os altamente escolarizados que vão forjando a tecnologia como arma de luta, à sua imagem e semelhança, e logo impondo sua eficiência e frieza como modelo da e na produção social. Homens e mulheres-máquinas, em diferentes locais da sociedade, acionam botões propulsores de uma produção acumulativa, competitiva, que se exibe em guerras "cirúrgicas" e técnicas como a do Golfo, que vimos tão recentemente pela televisão. Uma alegoria do produto escolar? Escolarizados que sabem engendrar esquemas potentes de destruição, que conhecem como intensificar os mecanismos de acumulação, mas desprezam a vida, são reféns de uma cultura que alterna como faca de dois gumes a permissão de matar e de sobreviver (Enzenberger, 1995).

Se o momento é de crise da própria civilização, dela só sairemos com uma escola que se refaça, escapando da reprodução do já feito, mas sem abandonar a longa estrada percorrida. Até porque sabemos que o passado não nos condena, desde que aprendamos a conjugar a tradição, extirpada do seu entulho conformista, com o esforço de criação do novo.

Sem um processo de escolarização vivo e duradouro, qualquer processo de democracia e desenvolvimento sofrerá de artificialidades intransponíveis.

A perversão do conformismo social com a negação escolar é tão mais grave porque vai conformando uma opção de escola que desde início vem marcando a sociedade brasileira: uma escola dual, que agora toma a forma de "escola apartada", para usarmos uma expressão de Cristovam Buarque, ou seja, fraturada e distanciada em suas partes por abismos que não param de se aprofundar. 
Sem que a sociedade brasileira assuma a escola como uma questão fundamental, continuaremos sem direção para o próprio sistema de produção e o próprio sistema político.

Produzir, para quê?

Controlar, com que direção, em que sentido?

Ingressar nos processos de mundialização só nos interessa se pudermos escolher a forma específica de nossa contribuição, como um exercício de liberdade e libertação próprio de sujeitos coletivos em tensão com sujeitos individuais.

Até agora, o crescimento da economia brasileira se fez pari passu com a concentração de bens e a ampliação da miséria.

Segundo divulgação do Unicef, o Brasil é o $6^{\circ}$ país, entre os piores do mundo em matéria de evasão escolar. Apenas 39\% dos que ingressam na $\mathrm{I}^{\mathrm{a}}$ série atingem a $5^{\mathrm{a}}$ série. Os companheiros recordistas em expulsão escolar (expressão que arranca esta realidade do eufemismo usual que é a evasão escolar) são pequenos países africanos, alguns com recentes processos de independência política, muitos em guerra interna, e com economia absolutamente insignificante, portanto, em nada comparáveis ao Brasil. Vale a pena reconhecêlos: Guiné Bissau (20\%), Etiópia (31\%), Moçambique e Angola (34\%), Madagascar (38\%).

Os números que retratam essa realidade assustadora para um país reconhecidamente pujante como o Brasil, com ilhas de sofisticação e prosperidade, não podem vir isoladamente. No ranking internacional, o professorado de São Paulo, o estado mais riço da Federação, ocupa uma posição inferior à de Bombaim, considerada na índia a cidade da miséria. Mas as comparações não param aí. Confrontado com o que foi há trinta anos atrás, o salário do professor sofreu uma redução de um quarto de seu valor ( Veja, 20/ 11/1991), ocupando um dos últimos lugares, entre os mais baixos do mundo.

Afinal, este é um problema em que as evidências vão exibindo um nível de gravidade que não pode passar despercebido. Quando comparado aos garis e mesmo a certos tipos de empregados domésticos, o professor do ensino básico público, na maioria dos casos, fica em desvantagem financeira. ${ }^{4}$

\footnotetext{
${ }^{4} \mathrm{~A}$ exceção mais clara se inscreve nas administrações do PT que, pela própria ideologia partidária, confere um tratamento especial à educação e à saúde.
} 
O número de pedidos de demissão da escola, depois de um concurso público, e até com a estabilidade garantida, bem nos dá a medida do desespero desses professores, frustrados em suas expectativas coletivas e individuais como classe popular, mestiços e mulheres.

No Rio de Janeiro, 20 pedidos diários de demissão da rede municipal e estadual (Veja, 24/5/1995) mostram uma realidade que se inscreve como frustração no cotidiano escolar. Para confirmar essa realidade captada por Chico Buarque de Holanda - a dor do povo, dos professores, aqui e acolá -, começa a aparecer nos jornais, apontando a população que mora nas ruas, como foi o caso notório da professora de Campos que se alojou debaixo da ponte (Jornal doBrasil,22/S/l9S9).

Mas, ainda, na grande imprensa, começam a aparecer publicidades assinadas por empresas, às vésperas das eleições de 1994, destacando o orçamento de 10 bilhões de dólares gastos com alunos repetentes, como uma maneira não só de alertar aqueles que com "boa-fé" compõem a elite, que têm negócios ou empregos e que, portanto, pagam a despesa com programas populares de educação, de que deveriam estar alertas em relação à má administração pública com todo o grande desperdício. Mas não param aí. Insinuam o prejuízo por tentar dar escola a quem não quer aprender. Velha tecla de culpabilização da vítima.

$$
\text { \# \# * }
$$

Num país com uma pós-graduação que já conta com a produção de mais de 6 mil dissertações, que alimenta um movimento editorial respeitável, grangeando uma expressão dentro e até fora do Brasil, como convivemos com este descalabro público?

Enquanto se difundem as comunicações via satélite e televisão a cabo, e antenas parabólicas emprestam às cidades e às suas periferias o aspecto de uma horta de cogumelos gigantes (Macaé constitui um exemplo concentrado deste tipo de paisagem), a escola pública se esvai, perdendo sua credibilidade e a identificação social do seu trabalho.

A constatação e o espanto fazem-se mais agudos quando confrontamos $\mathrm{o}$ alto teor de inventividade que percorre a cultura nacional, uma inventividade 
posta à prova, neste exercício diário de driblar ameaças de morte. Uma inventividade que parece condenada a ser mantida fora da escola, privando-a do trabalho de traduzir problemas que são ocultados como enigmas invisíveis em desafios formulados e discutidos pedagogicamente.

Como produzimos uma escola tão excludente que, à medida que cresce fisicamente, se desintegra internamente? Como mantemos uma instituição escolar que exclui do exercício de fazer-se sujeito de conhecimento mesmo aqueles que inclui dentre os seus pertencentes, professores e alunos?

Com o pulso escravocrata, o Brasil reservou a aprendizagem letrada para a classe dirigente, tanto que até na década de 20, apenas $25 \%$ da população brasileira sabiam 1er e escrever. Os restantes $75 \%$ se constituíam de analfabetos (Anuario Estatístico do Brasil, 1936). ${ }^{5}$ Agora que os pobres, sempre considerados a ralé que nada merece, entraram na escola, ela se torna diluída em ensinamento e perdida em termos de significação, sentido de vida, incapaz, portanto, de vertebrar um projeto pedagógico potente.

A escola ficou vazia de projetos. Até então, mesmo livresca, repetitiva e autoritária, ela veiculava os interesses da classe que ocupava as posições de mando e que, portanto, controlava a sociedade brasileira.

Agora, os que estão dentro dela têm cultura e interesses diferentes daqueles primeiros. Não lhes interessa conservar os privilégios que sempre os excluíram, mas fazer do saber escolar algo vivo para ser refeito, que lhes ajude a entender mais de si mesmos, entendendo mais os movimentos que vêm produzindo o Brasil; um saber escolar que contribua para a ampliação de escolhas, um saber aberto a virar ferramenta em suas mãos, para que possam formatar espelhos capazes de os refletir inteiros, em suas lutas e dificuldades, em seus sonhos e pesadelos, em suas alegrias e infortúnios; um saber que possa ser traduzido em narrativas em que o ser popular, o ser pobre, não se seja incompatível com a dignidade humana.

Mas é neste enclave que a proposta de uma escola verdadeiramente pública cai numa rota de colisão com o capitalismo e com as suas marcas próprias dentro da cultura brasileira, ambos forjados pela excludência: se na escola entram os pobres, a escola deve ser pobre, eis a conclusão perversa. 
Nesta colisão, ainda está presente mais um agravante: a democracia como um projeto de direitos universais, que precisava de professores para a difusão de ensinamentos cívicos, morais e racionais, considerados indispensáveis para a participação cidadã, vem sofrendo processos de encolhimento. Atualmente, sua imagem tem um ar constrangido de quem se faz e se refaz em gabinetes fechados, definindo regras para a legalização de sucessivas retiradas de direitos populares.

É em meio a esses movimentos que se pode entender o problema da escola pública: abandonada pelos governos, denegrida pela rede de informação social, escanteada do debate público, esvaziada teoricamente, ocupada transitoriamente por profissionais que tentam conciliar a própria sobrevivência com sua permanência na escola, sistematicamente corroída pelas profecias do "não tem mais jeito".

Os velhos esquemas de luta, como a greve, por exemplo, parecem não responder à magnitude do problema. A convicção de que é urgente instituir uma nova concepção e prática de escola só não é maior que a ausência de pistas concatenadas, por deficiência de uma reflexão teórico-pedagógica que conjugue os avanços do pensamento filosófico, das ciências sociais, da psicanálise e da literatura com o desejo de compartilhar o saber como um exercício de engrandecimento da vida humana e social.

Para não admitir o próprio e incômodo vazio, a escola se faz arrogante, como se herdasse a empáfia de classe patrimonialista e escravocrata que a mantinha ocupada e controlada. Por isso, além de vazia, a escola assume um ar pedante, distante de sua realidade social, dos pais de seus alunos, sobretudo, dos mais pobres, fazendo-se um espaço por onde ecoam gritos para manter a disciplina e por onde os silêncios significam, com freqüência, negação de

presenças indesejadas, impossibilidade de intervenções mais efetivas e criadoras. Mesmo sabendo das contradições, a força da hegemonia vai confirmando medrosos, fracassados e revoltados, uns e outros marcados por um espelho que os reflete no que eles têm de possibilidades, as mais negativas, devolvendo-lhe assim uma imagem autodesprezível. 
Esta é a nossa tragédia. Tragédia tão mais funda que se recusa a ser aliviada com ungüentos tecnicistas. Tragédia da qual não podemos nos livrar sem contarmos com os movimentos insütuintes com que os insatisfeitos buscam instalar caminhos de emancipação na sociedade e na escola.

Se nossa sociedade e nossa escola não tivessem que responder à demandados pobres, desses "trabalhadores sem trabalho", desses lavradores sem terra, desses "estudantes sem estudo", desses que, com dificuldade, entram na emergência dos "hospitais sem a esperança da saúde", bastariam remendos leves na política econômica, social e educacional. Mas pobres e miseráveis penetram na cidade, na escola e sacodem o presente e nos fazem olhar o futuro, num exercício ousado de instituir o novo ou abdicai" da democracia, da convivência, da própria humanidade.

Portanto, uma tragédia que não pode ser enfrentada só com os que estão dentro da escola, professores e alunos, supervisores, orientadores, administradores e seus auxiliares, mas que sem eles também não será resolvida. A eles cabe traduzir em saberes e fazeres escolares os projetos populares que vão sendo gestados pelos sujeitos históricos.

As pressões sociais para que um número crescente de pessoas possa usufruir do conhecimento escolar vêm sendo respondidas com escolas públicas desfibradas. A instituição escolar torna-se, assim, um tipo de confinamento institucionalizado cuja vantagem seria ocupar as crianças, transmitindo-lhe um saber sem sabor, impotente para fazê-las descobrirem-se vivas. A sua tarefa é impor aos alunos um tipo de disciplina e persistência que as disponha para lutar só pela sobrevivência, num processo de aniquilamento moral que tem como meta a resignação do perdedor.

Assim vai se delineando uma nova taxionomia para as instituições escolares (Dale apud Apple, 1993; Zemelman, 1993), as destinadas aos herdeiros dos triunfos da classe dirigente, com ciência, tecnologia e inventividade, capitaneadas para a competição - a chamada escola de mercado; as mantidas para preparar as "formigas" que engrossarão as filas dos que disputarão uma vaga no mundo dos empregos - a chamada escola mínima; e, finalmente, identificamos, um tipo degradado de escola, que mais se assemelha a um depósito 
de crianças e jovens, que prepara perdedores conformados - a subescola. Uma subescola para uma subclasse: os excedentes da sociedade de consumo.

Em primeiro lugar, não podemos extirpar da crise nem os riscos nem as oportunidades com que as encruzilhadas são feitas: nem só sonhos bons, mas tampouco pesadelos todas as noites.

É preciso, sim, indignar-se com os desacertos e os blefes consentidos e temer, responsabilizar-se e atuar para encontrar caminhos novos para a escola brasileira.

\section{Como despertar, se o pesadelo nos maltrata?}

Uma das árias da ópera inspirada no Werther, a obra apaixonada do jovem Goethe, tem um título muito expressivo: "Por que despertar se o sonho é tão bom?"

Recentemente, retomando contato com essa ópera, refleti o quanto o embalo do sonho, fechado nele mesmo, pode desviar do contato, às vezes doloroso, mas sempre rico, com a própria realidade. Se tudo está bem, para que despertar? Lembrei-me então de Milton Almeida dos Santos (Veja, 16/10/ 1994), em recente entrevista, depois do recebimento do prêmio internacional Vautrin Lud Vali, em que ele credita aos pobres a maior esperança de projetarmos uma sociedade mais solidária, pois sua presença nos faz perceber que não bastam remendos, mas sim que é preciso pensar o novo.

Não podemos embarcar no acalanto de sonhos que nos impeçam de ver e enfrentar a realidade. Sofremos de uma outra ameaça, um pesadelo, que igualmente nos priva de uma intervenção efetiva, tanto mais quanto nos mantém em estado de tensão e até nos impede de sonhar.

Robert Kurtz (1992) tem apontado que o colapso da modernidade vai arrastando um esgotamento de sonhos, expectativas e esperanças com que se alimentou a vida social. Dentro da problemática escolar podemos ver o crepúsculo de uma escola: forçada a declinar com um cerco material e cultural dos seus professores. Dentro dela, o foco dos olhares parece ser a 
porta de saída. ${ }^{6}$ Alguns esperam a aprovação no mestrado para, com uma bolsa, prepararem-se para avanços na carreira, atingindo a docência no $3^{\circ}$ grau. Outros buscam um novo emprego, pedem deslocamento para o trabalho administrativo, finalmente, requerem exoneração, aposentadoria precoce ou abandonam o emprego. Quem permanece na escola ainda desfruta de um horizonte onde seja possível desenhar projetos coletivos de um trabalho pedagógico?

Para onde foram as perspectivas de uma escola universal, interagindo com processos de democratização, ampliação de direitos civis e políticos, traduzidos no mundo do trabalho, na participação cidadã?

A escola parece agora não ter espaços para sonhos tão bons. Para sobreviver foi cedendo às imposições burocráticas, tecnicistas, imediatistas, particularistas, levada pelo comando capitalista, abdicando de perspectivas utópicas.

A aprendizagem escolar implica transmissões e aquisições que só são consolidadas mediante práticas recorrentes, onde o esforço de descoberta e a elaboração própria precisam ser insistentemente empenhados. Daí, todo o edifício da educação estar assentado num investimento que tem o futuro como alvo. Não podemos perder de vista que são os projetos, portanto as referências que ultrapassam o presente, que lhes dão sentido e organização. O próprio caos só pode ser organizado se visto para além da confusão aparente, pelo estabelecimento de relações, idéias, conjecturas e imagens que pode potencializar. São essas pistas, ainda que fugazes, que vão nucleando a constituição de um sentido, uma direção para a conduta, um significado para as ações humanas, sociais.

Quer sob as ameaças do pesadelo ou sob o embalo do sonho, há a tentação de deixar escapar o real. Este, indomável por qualquer teoria e planejamento, está ancorado num movimento de fabricação de sentidos que não pára de se retecer, se realinhar, nos surpreender pelas novas direções assumidas, ñutos de ações complexamente interligadas que vão demarcando as configurações históricas sempre em movimento.

${ }^{6}$ Pesquisa recente feita pelo sindicato de professores de Santa Catarina mostrou que um terço dos professores descja mudar de profisșăo (Veja, 24/5/1995). 
Mergulhados no sonho, podemos escapar da realidade para melhor enfrentá-la; podemos também nos fazer ausentes da trama histórica e acabar por perdê-la. Por outro lado, quando os sonhos se ausentam, o presente se desorganiza, as perspectivas que abrem o horizonte do amanhã se fecham; o hoje nos asfixia.

Todos sabemos que não arbitramos a hora de despertar do pesadelo que nos mantém como reféns de acontecimentos imaginários de alta densidade dramática, nos quais não podemos interferir.

Seria exagerado afirmar que estamos vivendo um pesadelo na escola pública brasileira? Ninguém deseja permanecer no pesadelo, mas a saída também não depende de atos deliberados só pela consciência, pela vontade. Para alguns professores, para acordar do pesadelo é preciso sair da escola. Entre o permanecer no pesadelo e o desligar-se da escola há registros que nos interessam investigar. Como despertar, organizar um alarme conjunto que, ao invés de sustos, precipitações, nos arme para uma construção de larga duração histórica? Com que instrumentos a supervisão pode contribuir para a saída do pesadelo? Como se entrelaçariam nesse trabalho os supervisores e os professores?

\section{Para que a supervisão? Entre o desgaste retórico da questão e o confinamento utilitário}

Como em outros temas, a problemática dos especialistas em educação parece uma questão desgastada. Tantas publicações, polêmicas que parecem acabar inócuas. $\mathrm{O}$ assunto parece desaparecer da cena dos debates, mesmo sem estar resolvido.

Em outra direção ocorrem movimentos que atribuem tarefas pontuais à supervisão ou aos especialistas, como se todo esse encaixe de trabalhos pudesse se isolar das interligações em que a própria identidade da escola se entrelaça com os rumos da sociedade.

Muito já se escreveu sobre a divisão de trabalho escolar e a hierarquização de competências para combater os especialismos pedagógicos. 
Embora não sejam nem um pouco desprezíveis as condições de nascimento da supervisão e demais habilitações com que a pedagogia se especializou no período da ditadura, entendo que a complexidade da sociedade e da escola brasileira comporta uma divisão técnica, desde que usada para fortalecer um trabalho pedagógico vincado por um projeto de escola, uma escola que não se mediocrize nem renuncie a si mesma em sua especificidade de instituição de ensino e aprendizagem, que nao possa deixar de responder aos apelos éticos que de forma intensa atravessam a atual crise da civilização.

A crítica pedagógica já denunciou com insistência a exclusão dos trabalhadores e dos pobres da escola. Mas pouco se tem falado de uma exclusão mais sutil, presente no próprio processo de inclusão, que vai demitindo professores e amortecendo alunos, num engessamento dos sujeitos na escola e sua paulatina reificação, sua redução a objetos repetidores.

Para encaminhar minha reflexão sobre a supervisão e a educação de professores no Brasil, vou tentar levantar duas questões intrínsecamente interdependentes e tecidas por uma densa multiplicidade de relações políticopedagógicas: a questão do sujeito e a questão do conhecimento escolar, para aproximar-me de algumas pistas que vão se delineando como possíveis, para professores, supervisores, orientadores, dirigentes, alunos e auxiliares da escola organizarem um solo de experiências e reflexões partilhadas de onde possam ser partejadas perspectivas de futuro.

\section{A questão do sujeito e do conhecimento escolar}

Na Grécia de Péricles (séc.V a.C), vamos encontrar o debate sobre a quem cabe ser o sujeito da verdade e quais as relações que o processo de conhecer, ensinar e argumentar deve manter com a política e os valores. Para os filósofos, a apreensão da verdade dependeria da contemplação de essências, que deveriam ser traduzidas com o rigor que só o pensamento conceituai poderia realizar. 
Extremas exigências pairavam sobre os filósofos, que deveriam pautar sua vida por um entranhamento entre saber e fazer, pela busca de aproximação dos valores, preservando o conhecimento de vínculos com os interesses subjetivistas e particularistas. A verdade, derivada de essências invariáveis, não poderia transmutar-se segundo o gosto e os interesses do auditório.

Os filósofos seriam os únicos habilitados e legitimados a traduzir as essências em conhecimento, estas sim passíveis de serem ensinadas.

Já os sofistas ensinavam a qualquer um, sem preocupações com a verdade, mas centrados na retórica do convencimento que garantisse a defesa de seus interesses. Para eles, o sujeito humano seria o espelho da realidade e, como esta é múltipla, também ele poderia abrigar uma série de perspectivas de conhecimento. Daí a célebre afirmação de Protagoras: "O homem é a medida de todas as coisas", que Pirandelo dramatizou na sua obra teatral Assim é, se lhe parece.

Na perspectiva sofistica, portanto, o conhecimento poderia ser sempre usado sem preocupações com o ideal da verdade, mas não podia prescindir do referendum das multidões. A verdade nem seria eterna e nem invariável - e a neutralidade impossível, diríamos, numa linguagem atual -, e todos os cidadãos teriam direito a disputar o consenso e tentar persuadir os demais sobre seus direitos, independente de qualquer conhecimento prévio.

Datam desta velha discussão embates que continuam absolutamente vivos e que carecem ser rediscutidos e revitalizados na escola. Que é conhecer? Quem pode conhecer? Para que se procura conhecer? Como os conhecimentos se tornam cúmplices dos poderes? Quais as dimensões éticas do conhecimento? Quais as relações entre conhecimento e verdade? O que significa a curiosidade por conhecer? Como o desejo de conhecer abre caminhos de descoberta, potencializadores da ação humana? Por que o saber e o desejo se entrelaçam na composição da alegria, da felicidade?

É possível ler no cotidiano escolar como no discurso pedagógico a presença daqueles dois antagonistas, sofistas e filósofos. Só que a história foi acrescentando outras dimensões àqueles embates gregos. 
O conhecimento visto como algo externo e imposição de um mundo real, continuamente ampliado e que temos de adquirir, está apoiado numa noção de razão onipotente e acumuladora de informações. Uma razão "educada", conquista o privilégio de uma elite com a qual os outros, "os não-educados", deveriam aprender, e que ainda está em vigência. Tanto os realismos propugnando a imposição do objeto sobre o sujeito do conhecimento - como os racionalismos - enfatizando as exigências metodológicas - reforçaram essa noção de conhecimento como acumulação para posteriores distribuições. Os mecanismos de produção e consumo do capitalismo industrial vêm reforçando a concepção do conhecimento como bagagem. $\mathrm{O}$ interacionismo, transação entre sujeito e objeto, evita o jugo do dado, presente no empirismo e no positivismo, e o voluntarismo, forte no racionalismo e no idealismo, ainda tem pouco vigor na escola, ainda que recorrentemente apareça no discurso pedagógico. Para a grande maioria dos professores, a concepção interacionista não ultrapassa a "esfera cerebrina", para usarmos uma expressão de Nobert Elias (1994).

Em estudo extremamente interessante realizado na Argentina, a pesquisadora Alicia Entel (1988) confirma o quanto a concepção de conhecimento na escola está carregada por uma imagem de "ente" exterior, um tipo de bagagem.

O culto dessa bagagem, a ênfase na sua independência e neutralidade, as promessas de um progresso sem limites, o investimento em projetos onipotentes de domínio e submetimento da natureza, para um possível e sempre transferido benefício da humanidade como um todo, foram marcos no desenvolvimento moderno dessa concepção.

Quando o humano foi considerado como alvo da ciência, um tipo de realismo psicológico localizou a essência como algo individual, interno e congênito, que deveria ser atendido, esculpido e libertado.

Mas toda a discussão sobre o conhecimento, os conteúdos e os métodos escolares parece ter desaquecido a problemática da verdade e da polifonia que a envolve.

Com a complexidade social que implica mediações e afastamentos entre os que produzem conhecimentos e os grupos que os absorvem e os consomem, 
o retorno à filosofia aparece como uma urgência para desfetichizar as ciências sociais (Heller, 1991).

Sem discutirmos as relações entre o conhecimento e a verdade, perdemos o solo natural para argüirmos os programas escolares. Quem os define? Com que critérios? Como nele estão inscritos os interesses de uma sociedade em conflito, que não pode ser identificada só com os interesses dos triunfadores? Qual o lugar para as lutas que buscaram construir uma sociedade mais justa? Como retomar o legado de projetos e esperanças que animaram a história? Como recolocar em pauta os anseios dos que foram derrotados? Como haurir dos conflitos sua força criadora?

Nunca é demais repetir que a crise ética se expressa e se aprofunda com os obstáculos à própria comunicação humana.

Se a verdade não é mais imutável e independente dos objetos e sujeitos, mas produzida continuamente pela história, sempre em movimento, a elaboração dos conhecimentos se faz num campo de batalhas, onde os interesses de classe e de grupos, com suas individualidades constituintes, se confrontam em conflitos abertos ou camuflados. A ciência e a filosofia passam a ser vistas não como a contemplação ou a captação de essências, mas como uma produção histórica que envolve processos de racionalização e abstração, podendo, portanto, não prescindir da prática social e da ação coletiva.

Os valores não são entidades superiores à história, magnetizando os humanos como deuses no Olimpo. Avaliar o que é verdadeiro e falso não depende de medidas externas com as quais vamos confrontar os fatos e as proposições com as quais tentamos traduzi-los. A expectativa de que o conhecimento pudesse repousar em certezas traduzidas em resultados insofismáveis e exatos, que privilegiaram a matemática como a linguagem preferencial e até exclusiva, com que os cientistas poderiam ter acesso aos segredos e mistérios da criação, já está incluída no acervo de mitos ultrapassados. Deles sobram sentimentos que se aproximam ao de uma certa orfandade: quem irá sancionar nossos acertos e erros? Qual o peso e a leveza de sermos sujeitos de nosso conhecimento? Com quem vamos dividir a responsabilidade de nossas escolhas, de nossas ações? Com quem podemos buscar pistas as mais satisfatórias para vencermos as 
inseguranças, as confusões e as ambigüidades, já que todo discurso é por si mesmo polissêmico?

As verdades e os conhecimentos são produzidos socialmente, dentro das lutas com que as condições da existência são engendradas. Como manter a objetividade se a luta para construir conhecimentos e defender a verdade passa por interesses em conflito, nos quais estamos ineludivelmente implicados? Como renunciar a neutralidade sem fazer da verdade uma causa menor, esvaziada de sua dimensão moral e ética? Quais as implicações de aceitarmos concepções tais como "verdade absoluta" e "verdade relativa"?

Se a verdade não se localiza fora, mas dentro da própria história, a neutralidade não será possível, mas não estamos nunca isentos de construirmos o mundo objetivo como uma tessitura voltada para a emancipação social, humana. Em nome de que e de quem um conhecimento pode ser declarado verdadeiro? Quais são os limites éticos que separam a argumentação da empulhação?

Se os valores se fazem nossos à medida que os traduzimos em ações e palavras ou em palavras e ações, será também por aí que eles serão construídos e confirmados nessa interação entre o sujeito que conhece, se exprime e age e o objeto que vai sendo conhecido. Essa interação feita por indivíduos carrega a tensão social, coletiva, histórica, as marcas da cultura com que é produzida e da liberdade com que o ser humano se define. Aí reside a nossa responsabilidade de sujeitos morais que somos.

\section{O saber com sabor na construção do sujeito do conhecimento}

Com a concepção de conhecimento visto como algo externo que devemos adquirir e que nós, professores, precisamos permanentemente obter e transmitir para fazer de nossos alunos seres "educados", a escola vem funcionando como uma usina de moer sonhos e fibras de sujeitos. O conhecimento, que deveria auxiliar os estudantes a se conhecer, conhecendo a história e os conflitos de seu povo, como vem sendo ensinado acaba por funcionar como mais uma rede de amordaçamento da voz e atrofia do pensamento. 
Sem os sujeitos do ensino e da aprendizagem, ou contra eles e seus interesses, o saber se faz amargo e com o sabor de derrota, como se fosse preciso quebrar-se a si mesmo para aprender.

Essa é uma das lições que Freire (1993), há mais de quatro décadas, insistentemente nos ensina: "a de que o conhecimento, quando movido por uma curiosidade que não foge aos compromissos políticos e éticos, nos insere num nível de prazer, que não significa facilidade e conforto".

É impressionante o número de cientistas e pensadores que revendo suas trajetórias de vida param nas lembranças da escola para focalizar o desperdício da paixão de apreender e o desvio da curiosidade e do interesse de buscar respostas, como forma potente de contribuir com a vida.

Há toda uma intersubjetividade escolar, educacional, que precisa ser recuperada, rememorada, para nesse exercício repensarmos as camadas da história que foram se naturalizando num senso comum pedagógico.

Na memória secular da escola e seus antecedentes, podemos encontrar tanto jograis, trovadores, cantadores e contadores épicos, bufões, narradores e poetas, que ora vagavam de lugar em lugar como detentores de um tipo de palavra pública, ora serviam em cortes, casas feudais e abadias ou ensinavam ao ar livre perto dos mercados (Manacorda, 1989), como aqueles copistas que caprichavam na caligrafia artística como uma forma de obter penitência e descontar pecados (Le Goff, 1989).

Tanto remetendo ao riso - que Rabelais já havia entendido como uma forma de afirmação da vida - quanto ao grotesco - tão presente na cultura medieval -, aquelas vozes itinerantes estremeciam a estabilidade dos dogmas, pela circulação de uma "literatura" que era recriada em cada apresentação e que se renovava em múltiplos contatos. Vozes que retrataram a posição da mulher: seus conflitos, suas condições de vida, suas resistências e suas surpresas, seus desejos e suas reversões. Vozes potentes que ameaçavam e que pagaram pela partilha da alegria instituinte nos tribunais da Inquisição. ${ }^{7}$ Vozes que vão expressando o declínio do feudalismo e do imediatismo das reações guerreiras e

'Quantos jograis e jogralesas, adivinhos e adivinhas foram condenados pela memória e pelo prazer que exibiam, visto que eram entendidos como perigosas parcerias com o diabo! 
abrindo canais para um outro estilo de paixões em que o lirismo e a conquista das mulheres passam por uma economia dos afetos, redefinindo as relações amorosas em meio a um interligamento de funções político-econômicas que conhecemos como "processo civilizador" (Elias, 1994).

Não podemos esquecer que o auge desta vocalidade criadora correspondeu a um período dos mais brilhantes da literatura medieval (Zumthor, 1993).

Talvez seja oportuno lembrar, como faz Enzenberger (1995, p.44), as nossas grandes dívidas para com as culturas analfabetas, posto que foram elas que inventaram a literatura, com suas "formas elementares, do mito à canção de ninar, do conto de fadas ao canto, da oração à charada[...]. Sem a transmissão oral não existiria a poesia, e sem os analfabetos não haveria livros."

Mas, se recuarmos um pouco mais no tempo, poderemos surpreender na história, nos fins do século VIII e começo do século IX, o que alguns historiadores como Le Goff denominam de Renascença Carolíngia, período marcado por uma extensa atividade de compilação das obras antigas, que se fazia simultaneamente ao fechamento das escolas externas aos mosteiros. Uma produção considerável de manuscritos respondia a um exercício de entesouramento e, portanto, sem a circulação e a divulgação vitalizadoras das obras. Apenas representavam valor econômico como os utensílios de prata. Mas, a própria feitura dos livros também representava uma obra de sacrifício e penitência que, no fundo, respondia a uma exigência de mortificação que poderia, numa contabilidade funesta, ser trocada pela garantia do céu.

Desta rápida olhada nesse "renascimento" tão avarento, recolhemos dois registros importantes:

1. a escrita, os títulos escolares e acadêmicos não podem ser considerados um valor em si, posto que eles se referem a uma compreensão da realidade e a uma atuação na vida, muitas vezes, servindo de obstáculos;

2. são profundas as raízes que tentam enlaçar os livros com o sacrifício sem grandeza, arrancando do processo de conhecimento seu mais potente vigor: a alegria da criação que se sustenta em sujeitos que conjugam saber e desejo. 
Uma e outra servem para nos mostrar como foi se preparando essa atual política de conhecimento que, por um lado, hierarquiza sem parar os saberes, desqualificando a vida em favor do cálculo utilitarista. De tudo isso resulta a expulsão da alegria como expressão de afirmação e criação da vida, para consolidar um adestramento de seres coisificados, verdadeiros objetos com movimento, submetidos às conveniências de uma "sobrevivência com alto padrão de qualidade e conforto".

No século XVI, Montaigne retoma de Rabelais a crítica da escola livresca, copista e burra, que empanturra o aprendiz com receitas e informações que só servem para impedi-lo de ser gente. O autor de Gargantua e Pantagruel mostrou o necrotério em que ritos vazios iam enterrando a esperança e a vida num extraviado processo de educação que nada significava para o educando, senão um exercício de negação que culminava com sua própria coisificação. Contra este desperdício de vida humana, Rabelais propôs o jogo, a brincadeira. "Ciência sem consciência não é senão ruína da alma" (Montaigne).

A própria ação do sujeito, Montaigne, como Rabelais, vincula a alegria de conhecer. Mas recusa com a maior veemência o ideal enciclopédico da "cabeça bem-cheia", enfatizando a "cabeça bem-feita". Para isto, ele acreditava ser essencial livrar-se das idéias já prontas e das lições encerradas pela provocação da curiosidade do aluno, aproveitando a matéria simples que a própria vida e a experiência nos vão fornecendo.

No fundo, a sua indignação dirige-se contra os processos que, em nome de uma cultura erudita e refinada, vão minando a força dos jovens e fazendo-os abatidos, passivos, acovardados. A partir deste entendimento, o autor dos Ensaios se contrapõe aos pedantismos das supostas culturas superiores e defende o direito da palavra do jovem aprendiz, e com ela a aventura de aprendizagens que fujam aos cânones da mesmice. Basta de enfeitar a sabedoria com este adorno pobre e feio que é uma suposta seriedade com a aparência de tristeza. Apesar do óbvio que este apelo trouxe, fortes razões, enraizadas em interesses e hábitos, se contrapuseram e ainda continuam em vigência contra a entrada das forças de criação no conhecimento escolar, que o tornaria potente para quem o organiza, o ensina e o aprende. 
A tristeza, a sisudez e o tom de sacrifício que de longas datas envolvem a escola, fazendo com que Shakespeare afirmasse que "o amor corre para o amor, como as crianças fogem da escola", não podem ser deslocados só pela força das novidades tecnológicas e do consumo pedagógico.

Ao invés de afirmar que as brincadeiras ou as novidades facilitariam o trabalho escolar e, por isso, deveriam ser injetadas no processo de ensinoaprendizagem, entendo que é a própria concepção de conhecimento e de escola que está em questão: um conhecimento sem mistério e sem enigmas, que deve ser carregado como um peso pela vida afora, subjugando, subalternizando, ou um processo escolar que participe da aventura humana, a qual não pode ser engessada num rol de utilidades imediatas, e que nos proponha questões, para cuja resposta possamos dialogar permanentemente com a vida num exercício de vida.

Por que a sabedoria vai se tornando antagônica aos bancos escolares?

Se esta questão tem sido respondida pela argumentação da força dos interesses capitalistas, como exigência de um processo disciplinador que, dominando a escola, aniquila a imaginação e o idealismo de lutar contra as opressões, de criar laços solidários, considerado até poucos anos atrás como uma característica dos jovens, ela não pode quebrar o vigor do saber empenhado em resolver desafios, investido em esperanças e projetos de quem ensina e de quem estuda.

\section{Memória e narração: biografia da escola}

Começamos esta comunicação falando do desastre que vem ocorrendo na escola púbüca, discutimos como professores e supervisores vivem um período de extremas dificuldades dentro da escola, posto que os problemas se acumulam e se exprimem com um tal nível de intensidade que cada susto, ainda sem ser superado, se confronta com a presença de outras ameaças mais assustadoras. Ao desmonte da escola e da preparação do professor dos anos 70, que correspondeu a uma alarmante evasão de alunos, vem se seguindo a extrema 
dilapidação do professor e de suas condições de trabalho, que o faz conviver com escola modernas e monumentais sem recheio pedagógico, ou com espaços obsoletos e malconservados. Nos anos 80, deu-se a evasão do professor, que continua aumentando. Nos anos 90, a violência urbana, as quadrilhas contraventoras decidem sobre o fechamento da escola, e o crime e a morte convivem e agravam velhos problemas escolares.

Nessa situação de caos e de portas fechadas, se inscreve um esgotamento de sonhos dentro da escola, evocando grande ameaça de convulsões intestinais, embates pela sobrevivência, sempre posta a perigo, produzindo uma miopia que retém no miúdo e nas soluções imediatistas os problemas da escola.

A trajetória de vida dos professores vem sendo estudada na literatura internacional através dos ciclos de vida correspondentes as seguintes fases: tensão e descoberta, estabilização e preocupação didática, sedimentação da experiência com emergência de novas idéias, autoquestionamento, serenidade e distanciamento afetivo, conservantismo e desinvestimento (Nóvoa, 1992). ${ }^{8} \mathrm{Na}$ escola brasileira, tal é a provisoriedade do vínculo de trabalho que aqueles professores com mais de quinze anos de exercício profissional já se tornam figuras raras.

Sabemos todos que um campo de conhecimento, de saber e fazer, não se desenvolve se não contarmos com indivíduos que invistam na sua construção sem uma visibilidade imediata. ${ }^{9}$ A provisoriedade, habitualmente, funciona como uma espécie de ácido corrosivo para a constituição de qualquer instituição social, como o próprio campo de conhecimento pedagógico, que se relaciona de diferentes maneiras com o status e as possibilidades da carreira profissional.

Para que os professores exerçam a docência com autonomia, precisam ir com ela construindo o reconhecimento da importância de sua função pela sociedade, expressa pelo salário e pelas condições de trabalho. É este

${ }^{8}$ Antes de Nóvoa (1992), histórias de vida de professores foram estudadas eomo método para entender o magistério e a educação de docentes por autores como: Ozouf, 1967; Muel, 1977; Huberman, 1987; Casey, 1992; Ball, Goodson, 1992.

'Dando a palavra a Bourdieu (1988, p.5!) vamos ouvi-lo enfatizando que: "Os campos sociais [...\} só podem funcionar na medida em que haja agentes que invistam neles, nos mais diferentes sentidos do termo investimento, e que lhes destinem seus recursos e persigam seus objetivos, contribuindo, assim, por seu próprio antagonismo, para conservar-lhes a estrutura, ou, sob certas condições, para transformá-los". 
reconhecimento que lhes garante e abastece de autoridade a função pedagógica, oferecendo um espelho, onde a imagem da profissão pode ser retocada e redefinida, num tipo de negociação com a sociedade, a escola e o próprio profissional.

A política de desqualificação da educação pública, em vigência em nosso país, vai cortando as possibilidades de autonomia do professor. Sem um salário digno e conduzido à subalternização, sem relação instituinte com o saber, a autoridade pedagógica enfrenta extremos desafios e ameaças.

À medida que o percurso do professor, dentro da escola, se torna algo passageiro, revestido de um caráter transitório em face das condições de trabalho que lhe são impostas, a convivência com os colegas se toma rarefeita e amarga, pelas desilusões da experiência sofrida e que ainda não foi trabalhada para liberar o sentido de dignidade, presente na luta de grande parte do professores e, pior ainda, destes muitas vezes ocultada.

Agravando essa situação, quase inexistem mecanismos para "amortecer" o choque da entrada dos professores na escola. Se a primeira fase da vida do professor, conforme a literatura especializada e já mencionada, aparece sob as formas de tensão e descobrimento, mesmo nos países onde a escola tem uma história de maior solidez, nos relatos de professores brasileiros, o exercício inicial consiste em verdadeiro ritual de "golpes", que poderíamos chamar "a peito aberto". Golpes tão fortes que parecem não contar com uma rede de significações que se entrelacem em projetos pedagógicos, quer de caráter político, quer de caráter social, coletivo e individual.

Sabemos que a estrutura institucional muda com mais rapidez do que as expectativas e imagens que dela guardamos. Até bem pouco tempo, ser professora denotava um alto prestígio social que levou as classes populares a investir neste tipo de formação, imaginando, através da carreira do magistério, alcançar prestígio e acesso a um tipo de "intelectual intermediário" (expressão de Gramsci), mas, também, contribuir para que as jovens pobres escapassem do trabalho manual, que além de pesado mantém conotações muito negativas na cultura ibero-americana.

Com uma formação deficiente e, ainda, com alguma idealização, os professores ingressam na carreira sem maiores respaldos. 
Em contraste com o campo educacional, encontramos nas profissões de prestígio, como Medicina e Direito, espaços organizados para favorecer a aprendizagem do que a tradição foi demarcando como essencial para os iniciantes.

No caso da escola, o supervisor poderia assumir este trabalho fazendose mediador entre os novatos e a experiência docente, experiência institucionalizada, vitalizada pela reflexão.

Uma das características de períodos históricos de intensa mutação como o nosso é o requerimento de qualificação e aperfeiçoamento continuados. $\mathrm{O}$ nível desta qualificação (mais criativa e autônoma, com o envolvimento do pensamento, ou mais reprodutora, adestradora e mecânica) tem sua correspondência nas hierarquizações concretizadas no mundo do trabalho.

No caso dos profissionais da educação, esta exigência se torna mais aguda pelo acelerado ritmo de avanço na construção de conhecimento, mas sobretudo pela crise de identidade que vem sofrendo a instituição escolar.

Para redefinirmos os rumos da escola, como um exercício de sujeitos, poderíamos entranhá-la de memória e narração.

Os parâmetros do conhecimento escolar estão de tal ordem contaminados pelo consumo da informação jornalística (acumulação, fragmentação capitalista e tecnicismo mecânico), com um tipo de positividade impondo a resignação, que se manifestam na concessão da sua própria domesticação, sob o controle rigoroso ou como negligência oficializada. Tudo isso leva a escola a sepultar as possibilidades de narração e de promoção de um tipo de processo de ensino e aprendizagem que investigue as necessidades históricas dos que buscam o saber, conjugando seus apelos coletivos com os individuais.

O entranhamento de memória e narração poderia fazer a escola recriarse como uma comunidade narrativa em que a biografia de cada instituição escolar servisse de fio condutor, para que professores e alunos fossem tomando contacto com as lutas de instalação da escola e com aquelas que vão incrementando o seu desenvolvimento. Isto implicaria retomar antigos problemas cujas soluções decorreram de árduo trabalho pedagógico absorvido, a ponto de ser naturalizado, mas também restaurar embates ainda não resolvidos e que esperam novas oportunidades de discussão e ação (Benjamin, 1985). 
Entrelaçados com o desenvolvimento da escola, os pólos de memoria e narração poderiam provocar as narrativas de professores, suas historias profissionais, os acontecimentos que eles testemunharam, os eventos sociais, os avanços e recuos de cada época. Enfim, a própria materialidade da escola seria explorada mediante um inventário (Gramsci) de marcas constituintes de nossa história, da história partilhada, como um campo onde pudéssemos revisitar nossas trajetórias e as singularidades de cada período (com suas turmas de professores e alunos), com suas conquistas e frustrações. Neste tecido narrativo, iriam aparecendo teorias e intuições, as entradas e saídas ou permanências e modificações vividas na e pela escola.

Todo este material, além de comunicado oralmente, poderia ser registrado por escrito, facilitando análises de assentamento e distância que ajudem a escola a escapar das fantasias onipotentes das lembranças sempre encantadas de um tempo de ouro em que, supostamente, a escola seria perfeita. Como lembra Ginsburg (1987), essas idealizações são alimentadas pela ausência de material escrito.

Instigando a escola a encontrar-se com o seu presente e futuro, pela via da restauração dos caminhos históricos, sociais e humanos de sua construção e pela apropriação partilhada de crenças e desejos para enfrentar medos e desafios, também a escola pode se organizar para um processo autodefinido de avaliação e realinhamentos na concepção e procedimentos didáticos.

Se os professores e alunos se assumirem como narradores e passarem a usufruir de um exercício de construção de narrativas, escolhendo o que lembrar, destacar, minimizar, esquecer, todo um tecido vivo ficará mais aberto à formação de vincos, por onde o ensinar e o aprender ganharão sentido capaz de fertilizar procedimentos didáticos.

Os que estamos dentro da escola, para melhor conhecê-la e nos conhecermos dentro dela, precisamos abrir espaços para recuperar a memória, exorcizar tanto esquecimento e, quem sabe, quando nos apropriarmos da escola pelas suas entranhas, teremos razões para comemorar as significações que dentro dela nos orgulharemos de construir.

É impressionante, por exemplo, quando revisitamos os registros de política educacional ou de história da educação brasileira, a ausência de movimentos docentes no Brasil, que tenham uma articulação aberta com os trabalhadores, antes da década de 70 . 
Tanto na Argentina ${ }^{10}$ quanto no Uruguai, ' ' com um sistema escolar mais fortalecido - como conseqüência de uma historia econômica e política - encontramos, desde o começo deste século, organizações de maestros mais articulados aos movimentos populares.

Mas o silêncio do professorado brasileiro pode exprimir tanto a ausência de movimentos orgânicos como a pobreza de instrumentos epistemológicos, capazes de captar processos de resistência e contraposição hegemônica ainda incipientes.

Se o movimento da Nouvelle Histoire libertou a História do registro positivista das grandes batalhas, sempre protagonizadas em nome dos que ocupam lugares oficializados de poder, semelhante esforço precisa ocorrer dentro das escolas para restaurar o cotidiano de professores e professoras que, ao lado dos alunos e do corpo administrativo, dão vida à escola.

Sabemos muito bem que a escola só funciona porque dentro dela estão professores e servidores que insistem em torná-la real, em reinventála, a despeito das negações de todas as ordens.

Quantas histórias surpreendentes têm professores, supervisores, orientadores, servidores e alunos para narrar?

Apesar de sermos uma instituição que não pode prescindir do exercício de vozes, parece que abafamos as vozes que lhes dão vida, fazendo delas eco de vozes distantes que foram cristalizadas nos livros ou burocratizadas nas pautas de controle das secretarias.

Através de narrativas abertas que, reclamando outras narrativas, tanto podem fecundar a organização escolar, a ação de currículos e programas, como, ainda, ganhar espaços privilegiados, verdadeiros pólos de memória e narração, a escola poderá apropriar-se do seu legado. Um dos mais importantes, mas que nem é considerado nos planos orçamentários, é o alto investimento de vida feito por sujeitos históricos, buscando atiçar as fagulhas do conhecimento como desdobramentos da curiosidade de saber, da necessidade de ter respostas e alegrias para o exercício de sua emancipação humana, sedenta de novos caminhos de solidariedade.

\footnotetext{
${ }^{10}$ A Primera Convención Americana de Maestros: primarios, secundarios y universitarios, realizada em Buenos Aires em 1928, já recomendava "às entidades do magistério uma vinculação efetiva com as organizações de trabalhadores, para secundar ativamente a obra de melhoramento cultural do proletariado americano..." (Rama, 1983).

"Em trabalho anterior (Linhares, 1993), trabalhamos as raízes populares da escola e da universidade no Uruguai e suas íntimas relações com a construção da identidade nacional e a luta dos trabalhadores. A autonomia universitária que implicou a participação de estudantes c egressos nas decisões universitárias foi conquistada em 1908.
} 
Provocando a restauração da memória, dada como perdida, o supervisor entrará em contacto com elementos que lhe ajudarão a entender a escola como um inventário de procedimentos pedagógicos que a academia nem pressente existir, até porque escapa a deduções e induções de pequeno alcance; este inventário menos visível se conjuga com sonhos que insistem tenazmente em emergir, animando as lutas escolares: projetos da intersubjetividade de professores e alunos que se encontraram e se encontram na escola.

Através dos pólos da memória e narração talvez se possa devolver a voz aos professores, retirá-los de um exercício em que sua voz é modelada como autoridade diante de uma sala de alunos pequenos, portanto, uma voz hierarquizada para fazê-la soar, singularmente, compondo uma comunidade de pares que entram em contato com outras dimensões do tempo escolar: um tempo pretérito, onde uma tradição e uma especificidade começam a ser produzidas, cobrando permanentes definições de rumo.

Além da especificidade do escolar que vai aparecendo, cada biografia da escola abre um registro de perdas e ganhos que representará um material rico para atuar e revitalizar o ensino-aprendizagem.

Através desses núcleos, internamente, as escolas poderão usufruir de um espaço pedagógico que fuja da carga administrativa que pesa nos Conselhos de Classe; através desses núcleos, uma rede de relações entre as escolas, as famílias de alunos e as comunidades pode ser estabelecida, como também entre as diferentes escolas e, ainda mais, entre estas e as universidades.

Dentro deles, poderão se articular os diferentes níveis da docência, atualmente tão segmentados, conjugando histórias de professores, de exprofessores e de professores de $\mathrm{I}^{\circ} \mathbf{e} 2^{\circ}$ graus aos de professores universitários.

\section{Referências bibliográficas}

APPLE, Michael W. Oficial knowledge: democratic education in a conservative age. New York: Routledge, 1993.226p.

BALL, Stephen, GOODSON, Ivor. Teachers' lives atui careers. London: [s.n.], 1992. 
BENJAMIN, Walter. Magia e técnica, arte e política: ensaios sobre literatura e história da cultura São Paulo: Brasiliense, 1985.253p. (Obras escolhidas, v.l).

BOURDffiU, Pierre. Lições de aula. São Paulo: Ática, 1988.

CANETTI, Elias. Massa epoder. São Paulo: Companhia das Letras, 1995.487p.

CASEY, Kathleen, ; answer with my life: life histories of women working for social change. [Si.]: University Press, 1992.

CASTELLO, José. Prefácio. In: COSTA, J. F. A ética e o espelho da cultura. Rio de Janeiro: Rocco, 1994. 180p. p.9-16.

CASTELLS, Manuel. El impacto de las nuevas tecnologias en la economia internacional. Madrid: Instituto de Estudios de Prospectiva, 1990.490p.

COSTA, Jurandir Freire. A ética e o espelho da cultura. 2.ed. Rio de Janeiro: Rocco, 1994. 180p.

ELIAS, Nobert. O processo civilizador: urna historia dos costumes. 2.ed. Rio de Janeiro: J. Zahar, 1994.2v.

ENTEL, Alicia. Escuela y conocimento. Buenos Aires: Miño y Dávila, 1988. 46p. (Cuadernos Fiasco).

ENZENBERGER, Hans Magnus. Medicinocridade e loucura e outros ensaios. São Paulo: Ática, 1995.

FREIRE, Paulo. Educação como prática de liberdade. Rio de Janeiro: Paz e Terra, 1967.

Pedagogia da esperança: um reencontro com a pedagogia do oprimido. 2.ed. Rio de Janeiro: Paz e Terra, 1993. 
GENSBURG, Carlo. O queijo e os vermes: o cotidiano e as idéias de um moleiro perseguido pela inquisição. São Paulo: Companhia das Letras, 1987.309p.

GRAMSCI, Antonio. Obras escolhidas. São Paulo: M. Fontes, 1978.421p.

HELLER, Agnes. A sociologia como desfetichização da modernidade. Novos Estudos, São Paulo, n.30,p.205-215,jul. 1991.

HUBERMAN, Michael. La vie des enseignants. Paris: [s.n.], 1987.

KURZ, Robert. O colapso da modernidade: da derrocada do socialismo de caserna à crise da economia mundial. Rio de Janeiro: Paz e Terra, 1992.

LE GOFF, Jacques. Os intelectuais na Idade Média. 2.ed. São Paulo: Brasiliense, 1989.252p.

LINHARES, Célia Frazão. A autonomia universitária e escolar e a formação do professor: Uruguai e Brasil. Cadernos Cedes, São Paulo, n.31, p.33-48,1993.

MANACORDA, Mário. História da educação: da antigüidade aos nossos dias. São Paulo: Cortez, 1989.382p.

MATTA, Roberto da. Carnavais, malandros e heróis: para uma sociologia do dilema brasileiro. 5.ed. Rio de Janeiro: Guanabara, 1990.287p.

MUEL, Francine. Les Instituteurs, les paysans etL' Ordre Républicain: actes de la recherche en sciences sociales. Paris: [s.n.], 1977.

NÓVOA, Antonio et al. Vidas de professores. Porto: Porto Ed., 1992.214p.

OZQIJFJacques.Nouslesnuãtwsd'école.[S.L.S.n.], 1967. (Collection ArchiarsJulliard). 
PASOLINI, Pier Paolo. Os jovens infelizes: antologia de ensaios corsários. São Paulo: Brasiliense, 1990.252p.

RAMA, German. Mudanças educacionais na America Latina: situação e condições. [S.I.: s.n.], 1983.

RIBEIRO, Darcy. O povo brasileiro: a formação e o sentido do Brasil. São Paulo: Companhia das Letras, 1995.470p.

RIBEIRO, Maria Luiza. História da educação brasileira: a organização escolar. 4.ed. São Paulo: Moraes, 1982. 166p.

ZEMELMAN, Hugo. Conferência. In: SEMINÁRIO. A crise dos paradigmas e a produção do conhecimento. Niterói: UFF, 1993.

ZUMTHOR, Paul. A letra e a voz: a literatura medieval. São Paulo: Companhia das Letras, 1993.324p.

Recebido em 7 de dezembro de 1995.

Célia Frazão Linhares, doutora em Filosofia da Educação pela Universidade Nacional de Buenos Aires, é professora titular de Política Educacional no Instituto de Ciências Humanas e Filosofia da Universidade Federal Fluminense (UFF).

The Brazilian social and educational tragedy continues and grows deeper as a result to the absence in Brazilian society of a combination of forces representing a passion to revert it. A political passion interweaving with a search for knowledge feeding on a curiosity to flavour is implied in the expansion and appropriation of knowledge by the action of historical subjects involved in it. One of the ways for us to reinvent Teachers ' Education 
is io unueriuKe an urcneoiogy oj scnooi in searcn oj ureums ana cunjucis experienced in the school to resignify them as projects of a new school instituion.

La tragédie sociale et éducationnelle brésilienne persiste et s'approfondit du fait de l'absence, dans la société brésilienne d'un ensemble de forces exprimant une volonté passionnée de renverser cette situation. Une volonté faite de passion politique entrelacée de recherche de savoirs et connaissances, nourrie de curiosité pour comprendre les mécanismes de l'oppression, reflétant une forme d' affirmation de la vie, dont la saveur soit impliquée dans la croissance et l'appropriation du savoir par l'action des sujets historiques qui y prennent part. Une des voies capables de nous mener à la réinvention de l'Education des Professeurs serait d'entreprendre une "archéologie de l'école ", à la recherche des rêves et conflits déjà vécus en son sein, afin de les re-signifier et d'en faire les projects d'une nouvelle institution scolaire.

La tragedia social y educacional brasileña persiste y se profundiza por la ausencia, en la sociedad brasileña, de una conjugación de fuerzas que represente una pasión para revértela. Una pasión política que se entrelace con la búsqueda de saberes y de conocimientos que se alimente de una curiosidad por comprender los mecanismos de opresión, como una forma de afirmación de la vida, en que el sabor estea implicado en la ampliación y apropiación del saber pela acción de los sujetos históricos en el involucrados. Una de las vias para reinventarmos la Educación de Profesores es emprender una "arqueologia de la escuela ", en la búsqueda de sueños y conflictos en ella ya vividos para resignificarlos en proyectos de una nueva instituición escolar. 